\title{
GENE ACTION AND COMBINING ABILITY FOR NEPS AND SEED COAT NEPS IN COTTON (Gossypium hirsutum L.)
}

\author{
Aydin $U N A Y^{I^{*}}$, Serife BALCI ${ }^{2}$, Volkan Mehmet CINAR \\ ${ }^{1}$ Aydın Adnan Menderes University, Faculty of Agriculture, Department of Field Crops, Aydın, TURKEY \\ ${ }^{2}$ Cotton Research Institute, Nazilli-Aydin, TURKEY \\ ${ }^{3}$ Aydin Adnan Menderes University, Graduate School of Natural and Applied Sciences, Aydin, TURKEY \\ *Corresponding author: aunay@adu.edu.tr
}

Received: 21.05.2019

\begin{abstract}
Information about heritability and combining ability for neps and seed coat neps is necessary for the cotton breeding strategies. Seven cotton cultivars including 4 lines and 3 testers were mated in line $x$ tester mating design. The 19 genotypes were grown in RCBD with three replications in Aydın-Turkey conditions during 2014 growing season. Non-additive gene action was important in the expression of seed coat nep size, nep count and nep size. The parental lines Carmen and Claudia were good combiners for most neppiness characteristics. Carmen x Flash, Julia x ST-468, Claudia x Carisma and Gloria x Flash were the superior crosses for selection in further generations of neppiness breeding. It was recommended that the selection of individual plants for neppiness should be performed in later generations $\left(\mathbf{F}_{4}-\mathbf{F}_{6}\right)$.
\end{abstract}

Key words: Combining ability, cotton, gene action, neps, seed coat neps

\section{INTRODUCTION}

Cotton is an important and strategic crop that has multiple contributes for the economy, widely grown in 53 countries in the world. In the 2017/18 season, global cotton production grew by $17 \%$ to 26.8 million tons, following the $7 \%$ production growth of the previous season. Turkey ranks ninth in the cotton sowing area, eighth in cotton production, second in cotton yield, fourth in cotton import and cotton consumption in the world (Anonymous, 2018).

Cotton breeding for fiber quality improvements has long been a primary objective of breeders. One important problem for early breeders was the lack of reliable and rapid methods to measure fiber characteristics (Baldwin et al., 1995). The AFIS (Uster Advanced Fiber Information System) instrument sizes and counts neps and seed coat neps in the lint stream. Neps and seed coat fragments remaining in fibers severely affect textile processing during spinning and dyeing (Jacobsen et al., 2001; Tekinsen, 2005; Bel and Xu, 2011). Because seed coat fragments remain in processed cotton attached to fibers, they can affect yarn quality and final fabrics by causing dyeing difficulties and holes in fabrics after "the dissolution of the seed coat tissue" (Pearson, 1955; Krifa et al., 1999). The genotypic differences and heritability on AFIS data for neps and seed coat neps have been few studies. Significant differences for neps and seed coat neps were identified among cotton cultivars in both $G$. hirsutum L. and G. hirsutum L. x G. barbadense L. hybrid populations (Mangialardi and Lalor, 1990; Boykin, 2008; Zeng and Meredith, 2010). The information on gene action and combining ability of neps and seed coat neps are needed to identify the suitable parents and promising cross combination in breeding program. Zeng and Bechere (2012) reported that neps and seed coat neps are controlled by additive gene effect due to higher general combining ability variance than that of specific combining ability.

There is a general lack of information on gene action and combining ability of neps and seed coat neps in cotton. This study was aimed to estimate gene action for neps and seed coat neps in line $\mathrm{x}$ tester population and identify good combiners for these traits. The results of the present study can help predict the potential of genetic improvement for these important for fiber nep characteristics in cotton cultivars.

\section{MATERIALS AND METHODS}

The genetic population was developed from crossing four lines; Gloria, Claudia, Carmen, and Julia, and three testers; ST-468, Carisma and Flash using line $\mathrm{x}$ tester mating design in cotton (Gossypium hirsutum L.). The varieties used as line and tester were deliberately selected for high fiber quality characteristics and well adaptive capacity, respectively. Our preliminary studies (unpublished) had showed that cultivars used as lines were lower SCN count (11.25-16.70 number $\left.\mathrm{g}^{-1}\right)$ than testers 
(25.80-34.75 number $\mathrm{g}^{-1}$ ). Totally 19 genotypes, 7 parents and their $12 \mathrm{~F}_{1}$ crosses were grown in randomized complete block design with three replications at Cotton Research Institute, Nazilli, Aydın/Turkey. Parents and crosses were hand sown in single row of $12 \mathrm{~m}$ length, the rows and plant spacing was 0.7 and $0.2 \mathrm{~m}$ in May 2014. All the cultural managements such as fertilization and irrigation were applied as recommended for the cotton growing of Aegean Region. Twenty plants were randomly selected from $F_{1}$ 's and parents. A 20-boll sample was hand harvested from middle fruiting positions of selected plants. Samples were ginned on laboratory-type roller gins with no lint cleaning. Fiber properties of nep size $(\mu \mathrm{m})$, nep count (number $\mathrm{g}^{-1}$ ), seed coat nep size (SCN; $\left.\mu \mathrm{m}\right)$ and seed coat nep count ( $\mathrm{SCN}$; number $\mathrm{g}^{-1}$ ) were measured using USTER AFIS (Figure 1) by ISKUR Textile Company.

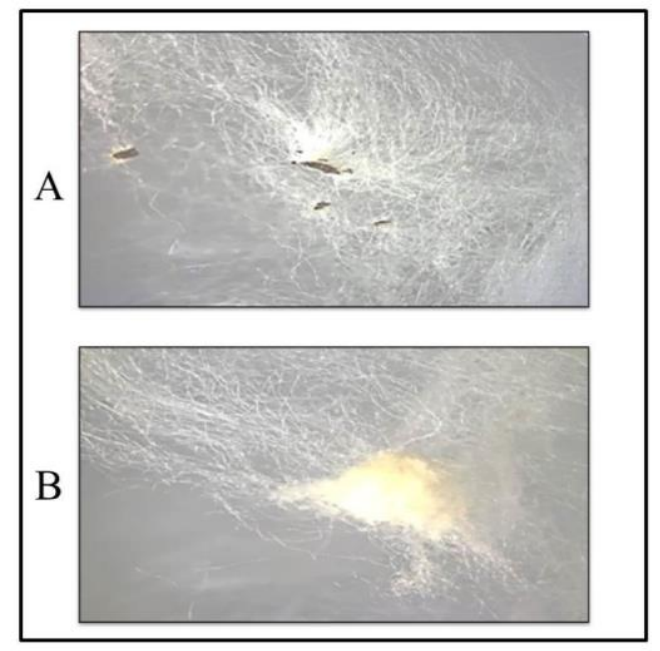

Figure 1. Seed Coat Neps (A) and Fiber Nep (B)

The combined analysis of parents and crosses was done as suggested by Arunachalam (1974) and for combining ability analysis, the following model was used:

$$
\begin{aligned}
& \mathrm{Y}_{\mathrm{ijk}}=\mu+\mathrm{f}_{\mathrm{i}}+\mathrm{m}_{\mathrm{j}}+(\mathrm{mf})_{\mathrm{ij}}+\mathrm{b}_{\mathrm{k}}+\mathrm{e}_{\mathrm{ijk}} \\
& (\mathrm{i}=1,2 \ldots \mathrm{t}, \mathrm{j}=1,2 \ldots \mathrm{t}, \mathrm{k}=1,2 \ldots \mathrm{r})
\end{aligned}
$$

where $\mathrm{Y}_{\mathrm{ijk}}$ denotes the observation recorded on the (i $\mathrm{x}$ j) th cross in the $\mathrm{k}$ th replication; $\mu$ is the general effect; fi is the effect of the $i$ th line; $m j$ is the effect of the $j$ th tester; sij is the specific combining ability (SCA) effect of the (i x j) th cross; bk is the $\mathrm{k}$ th block effect and $e_{i j k}$ is the environmental effect (random error) associated with the (ijk) th observation which is assumed to be normally and independently distributed with a mean of zero and variance $\left(\sigma^{2}\right)$.

$\sigma_{\mathrm{f}}^{2}$ and $\sigma_{\mathrm{m}}^{2}$ represent fixed type variances for lines and testers respectively. The weighted average of these two can be taken as an estimate of $\sigma^{2} \mathrm{GCA}$, i.e.

$$
\sigma^{2} \mathrm{GCA}=\left[(1-1) \sigma_{\mathrm{f}}^{2}+(\mathrm{t}-1) \sigma_{\mathrm{m}}^{2}\right] /(1+\mathrm{t}-2)
$$

The ratio $\sigma^{2} \mathrm{GCA} / \sigma^{2} \mathrm{SCA}$ will give an approximate idea about degree of dominance (Kaushik et al., 1984).

The variance analysis of line $\mathrm{x}$ tester suggested by Singh and Chaudhary (1979) were estimated using Microsoft Excel. Combining ability effects were computed for seed coat nep, seed coat nep size, number of nep and nep size.

\section{RESULTS AND DISCUSSION}

Significant variation was determined among genotypes for all the characters under study (Table 1). This reflects sufficient genetic variability and allows combining ability analysis. Also, it was shown that lines contributed higher for neppiness in this population because of significant differences among lines for SCN count, SCN size and nep size while non-significance for testers (Table 1). Genotypic differences for neppiness were determined by Mangialardi and Lalor (1990), Boykin (2008), Zeng and Meredith (2010) in cultivated species of cotton ( $G$. hirsutum L. and G. barbadense L.).

Estimates of GCA and SCA variance ratio $\left(\sigma^{2}\right.$ GCA / $\sigma^{2} \mathrm{SCA}$ ) which was smaller than unity revealed that nonadditive gene action for the control of SCN size, nep count and nep size was higher than additive gene action (Table 1). The finding of non-additive gene effects do not corroborated by findings of Zeng and Bechere (2012) who observed greater $\sigma^{2}$ GCA than $\sigma^{2}$ SCA for neppiness in a hybrid populations involved exotic germplasm lines $\mathrm{x}$ elite germplasm in a North Carolina Design II. However, additive gene action for SCN count was found to be important in our population as reported by Zeng and Bechere (2012). The preponderance of non-additive type of gene actions clearly indicated that selection of superior plants, in terms of neppiness, should be postponed to later generation.

The mean square of parents vs hybrids for only nep size indicated that difference between the mean of parents $(683.1 \mu \mathrm{m})$ and hybrids $(651.7 \mu \mathrm{m})$ was significant (Table 1 and Table 2). In respect of neppiness, reduction in count and size of nep and SCN can improve yarn performance and fabric color quality (Mangialardi and Lalor, 1990). Among parents, testers, Flash, Carisma and ST-468 cultivars, were noteworthy as the parents with the worst fiber characteristics (Table 2). The lines, Claudia, Gloria, Julia and Carmen, were genotypes with lower nep count and size of fiber and SCN count. This confirms that lines and testers were deliberately selected for high fiber quality characteristics and well adaptive capacity, respectively as given in material and methods. Significant negative (desired) GCA effect of Claudia for SCN and nep count; Carmen and Flash for SCN size; Carmen for nep size was useful for the breeding of neppiness. No parent was identified with mean values and favorable GCA effects in all neppiness traits. Therefore, multiple crossing will be necessary to enhance recombination among parents. 
Table 1. Mean squares for observed characters

\begin{tabular}{|c|c|c|c|c|c|}
\hline & df & $\begin{array}{c}\text { SCN } \\
\left(\text { Number } \mathbf{g}^{-1}\right)\end{array}$ & $\begin{array}{c}\text { SCN } \\
\text { Size }(\mu \mathrm{m})\end{array}$ & $\begin{array}{c}\text { Nep } \\
\left(\text { Number } g^{-1}\right)\end{array}$ & $\begin{array}{c}\text { Nep } \\
\text { Size }(\mu \mathrm{m})\end{array}$ \\
\hline Block & 2 & 3.84 & 24775.18 & 299.01 & 3146.68 \\
\hline Genotypes & 18 & $314.05 * *$ & $135228.51 *$ & $552.15^{*}$ & $26336.38 * *$ \\
\hline Parents & 6 & $589.71 * *$ & $279073.08 *$ & $921.09 * *$ & $72225.87 * *$ \\
\hline Parents vs Hybrids & 1 & 48.32 & 6989.60 & 897.52 & $13133.85 * *$ \\
\hline Hybrids & 11 & 187.84 & $68425.92 * *$ & 319.52 & $2505.99 *$ \\
\hline Lines & 3 & $404.99 *$ & $91462.71 *$ & 474.62 & $3709.51 *$ \\
\hline Testers & 2 & 46.36 & 61035.53 & 155.58 & 70.19 \\
\hline Line $\mathrm{x}$ Tester & 6 & 126.43 & $59370.91 *$ & 296.62 & $2716.15^{*}$ \\
\hline Error & 36 & 108.02 & 22815.82 & 222.01 & 1051.22 \\
\hline General & 56 & & & & \\
\hline$\sigma^{2}(\mathrm{GCA})$ & & 30.95 & 3565.75 & 19.77 & 110.37 \\
\hline$\sigma^{2}(\mathrm{SCA})$ & & 6.13 & 12185.02 & 24.88 & 554.97 \\
\hline$\sigma 2(\mathrm{GCA}) / \sigma 2(\mathrm{SCA})$ & & 5.04 & 0.29 & 0.79 & 0.19 \\
\hline
\end{tabular}

*, **; significant at $1 \%$ and $5 \%$ probability level, respectively.

Table 2. Mean values and combining ability effects of parents and crosses

\begin{tabular}{|c|c|c|c|c|c|c|c|c|}
\hline \multirow{2}{*}{$\begin{array}{l}\text { Parents } \\
\text { Lines }\end{array}$} & \multicolumn{2}{|c|}{$\begin{array}{c}\text { SCN } \\
\left(\text { Number } \mathbf{g}^{-1}\right)\end{array}$} & \multicolumn{2}{|c|}{$\begin{array}{c}\text { SCN } \\
\operatorname{Size}(\mu \mathrm{m})\end{array}$} & \multicolumn{2}{|c|}{$\begin{array}{c}\text { Nep } \\
\left(\text { Number } g^{-1}\right)\end{array}$} & \multicolumn{2}{|c|}{$\begin{array}{c}\text { Nep } \\
\text { Size }(\mu \mathrm{m})\end{array}$} \\
\hline & Mean & GCA & Mean & GCA & Mean & GCA & Mean & GCA \\
\hline Gloria & $8.0 \mathrm{bc}$ & $9.64 *$ & $931.3 \mathrm{c}$ & -7.25 & $21.0 \mathrm{~b}$ & 6.13 & $581.6 \mathrm{~d}$ & -12.94 \\
\hline Claudia & $2.6 \mathrm{c}$ & $-5.91 *$ & $1159.0 \mathrm{~b}$ & $123.75^{*}$ & $24.6 \mathrm{~b}$ & $-9.63^{*}$ & $636.3 \mathrm{bc}$ & 4.94 \\
\hline Carmen & $12 \mathrm{bc}$ & -2.13 & $1868.3 \mathrm{a}$ & $-122.81 *$ & $35.3 \mathrm{~b}$ & -1.52 & $661.6 \mathrm{~b}$ & $-18.50 *$ \\
\hline Julia & $4.0 \mathrm{bc}$ & -1.58 & $1243.0 \mathrm{a}$ & 6.30 & $40.0 \mathrm{~b}$ & 5.02 & $641.3 \mathrm{bc}$ & $26.50 *$ \\
\hline \multicolumn{9}{|l|}{ Testers } \\
\hline ST- 468 & $26.6 \mathrm{ab}$ & 0.19 & $1060.6 \mathrm{bc}$ & -14.47 & $30.0 \mathrm{~b}$ & 3.16 & $1030.0 \mathrm{a}$ & -2.64 \\
\hline Carisma & $10.6 \mathrm{bc}$ & 1.86 & $1069.3 \mathrm{bc}$ & $77.44 *$ & $73.3 \mathrm{a}$ & 0.75 & $628.6 \mathrm{~b}-\mathrm{d}$ & 0.53 \\
\hline Flash & $41.3 \mathrm{a}$ & -2.05 & $1171.6 \mathrm{~b}$ & $-62.97 *$ & $45.3 \mathrm{a}$ & -3.91 & $602.6 \mathrm{~cd}$ & 2.11 \\
\hline $\operatorname{LSD}_{(0.05)}$ & 23.03 & & 205.13 & & 24.5 & & 47.2 & \\
\hline Mean & 15.05 & & 1215 & & 38.5 & & 683.1 & \\
\hline SE (Lines) & & 4.89 & & 71.2 & & 7.02 & & 15.2 \\
\hline SE (Testers) & & 4.24 & & 61.6 & & 6.08 & & 13.2 \\
\hline Hybrids & Mean & SCA & Mean & SCA & Mean & SCA & Mean & SCA \\
\hline Gloria x ST- 468 & $14.00 \mathrm{bd}$ & $-8.97 *$ & $1355.3 \mathrm{ab}$ & $185.25^{*}$ & $47.3 \mathrm{ab}$ & -8.72 & $650.3 \mathrm{~b}$ & 14.19 \\
\hline Gloria x Carisma & $31.33 \mathrm{a}$ & 6.69 & $1235.6 \mathrm{a}-\mathrm{c}$ & -26.33 & $54.6 \mathrm{ab}$ & 1.02 & $622.0 \mathrm{~b}$ & -17.30 \\
\hline Gloria x Flash & $23.00 \mathrm{ab}$ & 2.27 & $962.6 \mathrm{de}$ & $-158.91 *$ & $56.6 \mathrm{a}$ & 7.69 & $644.0 \mathrm{~b}$ & 3.11 \\
\hline Claudia x ST- 468 & $9.00 \mathrm{bd}$ & 1.58 & $1184.3 \mathrm{a}-\mathrm{e}$ & -116.7 & $48.6 \mathrm{ab}$ & 8.39 & $661.1 \mathrm{ab}$ & 7.63 \\
\hline Claudia x Carisma & $8.00 \mathrm{~cd}$ & -1.08 & $1362.3 \mathrm{ab}$ & -30.66 & $32.0 \mathrm{ab}$ & -5.86 & $641.6 \mathrm{~b}$ & -15.52 \\
\hline Claudia x Flash & $4.67 \mathrm{~d}$ & -0.50 & $1400.0 \mathrm{a}$ & $147.41 *$ & $30.6 \mathrm{ab}$ & -2.52 & $666.6 \mathrm{ab}$ & 7.88 \\
\hline Carmen x ST- 468 & $11.00 \mathrm{bd}$ & -0.19 & $1053.0 \mathrm{c}-\mathrm{e}$ & -1.52 & $57.0 \mathrm{a}$ & 8.61 & $652.6 \mathrm{~b}$ & 22.08 \\
\hline Carmen x Carisma & $14.67 \mathrm{bd}$ & 1.80 & $1219.6 \mathrm{a}-\mathrm{d}$ & 73.22 & $49.3 \mathrm{ab}$ & 3.36 & $623.0 \mathrm{~b}$ & -10.75 \\
\hline Carmen x Flash & $7.33 \mathrm{~cd}$ & -1.61 & $934.3 \mathrm{e}$ & -71.69 & $29.3 \mathrm{~b}$ & -11.97 & $624.0 \mathrm{~b}$ & -11.33 \\
\hline Julia x ST- 468 & $19.33 \mathrm{a}-\mathrm{c}$ & 7.58 & 1116.6 b-e & -66.97 & $46.6 \mathrm{ab}$ & -8.27 & $631.6 \mathrm{~b}$ & $-43.91 *$ \\
\hline Julia x Carisma & $6.00 \mathrm{~cd}$ & -7.41 & $1259.3 \mathrm{a}-\mathrm{c}$ & -16.22 & $54.0 \mathrm{ab}$ & 1.47 & $722.3 \mathrm{a}$ & $43.58 *$ \\
\hline Julia x Flash & $9.33 \mathrm{~b}-\mathrm{d}$ & -0.16 & $1218.3 \mathrm{a}-\mathrm{d}$ & 83.19 & $54.6 \mathrm{ab}$ & 6.80 & $680.6 \mathrm{ab}$ & 0.33 \\
\hline Mean & 13.14 & & 1191.8 & & 46.75 & & 651.7 & \\
\hline $\operatorname{LSD}_{(0.05)}$ & 14.05 & & 269.9 & & 27.0 & & 60.8 & \\
\hline SE (Crosses) & & 8.48 & & 123.3 & & 12.16 & & 26.4 \\
\hline
\end{tabular}

*, **; significant at $1 \%$ and $5 \%$ probability level, respectively.

Among crosses, three to twelve hybrids were detected significant and desired SCA for different neppiness. These hybrids were Gloria x ST-468 for SCN count; Gloria x Flash for SCN size and Julia x ST-468 for nep size. In terms of mean values and negative SCA effects Claudia hybrids (x Flash and x Carisma), Carmen x Flash and Julia $\mathrm{x}$ Carisma were the best combinations with lower of SCN count. Carmen x Flash and Julia x ST-468 for SCN size; Carmen x Flash and Claudia x Carisma for nep count presented superior values while Gloria x Carisma, Carmen x Flash and Carmen x Carisma hybrids were combinations for nep size. The hybrids with favorable means, higher and positively SCA effects and involving at least one of the parents with suitable GCA effects have great 
importance for favorable alleles to breed neppiness in this study (Kenga et al., 2004).

Similar to parents, it was seen that hybrid combinations with favorable mean values and SCA effects for all neppiness characteristics were obtained in these populations. However, Carmen x Flash, Julia x ST-468, Claudia x Carisma and Gloria x Flash can be identified as promising hybrids. Especially, parents as used lines of mentioned 4 hybrids exhibited favorable means and GCA, although all cultivars as testers had poor neps characteristics. SCA effects of mentioned could result from mating any combination of high (Gloria and Julia) and low (ST-468) GCA parents.

\section{CONCLUSIONS}

The genetic variability originated from parental lines for neppiness in the studied population. The lines, Carmen and Claudia cotton genotypes, were good combiners to decrease the nep and seed coat nep in breeding of neppiness. Non-additive gene action was higher than additivity in inheritance of nep and seed coat nep. The preponderance of non-additive type of gene actions clearly indicated that selection of superior plants should be postponed to later generations. Also, bulk method between $\mathrm{F}_{2}$ and $\mathrm{F}_{6}$ generations can be used successfully for advancing progeny generations. Carmen $\mathrm{x}$ Flash, Julia $\mathrm{x}$ ST-468, Claudia x Carisma and Gloria x Flash populations with desired mean values and SCA effects should be recommended for selection in further generations.

\section{LITERATURE CITED}

Anonymous, 2018. ICAC, International Cotton Advisory Committee, 2018. 2018/19 Outlook - Consumption Outpacing Supply Amidst Global Trade Challenges.

Arunachalam, V.C. 1974. The fallacy behind the use of a modified line $\mathrm{x}$ tester design. Indian Journal of Genetics. 34: 280-287.

Baldwin, J.C., M. Qaud and A.C. Schleth. 1995. AFIS seed coat nep measurement. In Proceeding of the Beltwide Cotton
Conferences, p. 1250-1251. San Antonio. TX. 4-7 Jan. 1995. Natl. Cotton Council Am., Memphis. TN.

Bel, P.D. and B. Xu. 2011. Measurements of seed coat fragments in cotton fibers and fabrics. Textile Research Journal 81(19): 983-1994.

Boykin, J.C. 2008. Seed coat fragments, motes and neps; cultivar differences. Journal of Cotton Sciences 12:109-125.

Jacobsen, K.R., Y.L. Grossman, Y.L. Hsieh, R.E. Plant, W.F. Lalor and J.A. Jernstedt. 2001. Neps, seed-coat fragments, and non-seed impurities in processed cotton. Journal of Cotton Science 5(1): 53-67.

Kaushik, L.S., D.P. Singh and R.S. Paroda. 1984. Line x tester analysis for fixed effect model in cotton (Gossypium hirsutum L.). Theoretical and Applied Genetics. 68: 487491.

Kenga, R., S.O. Alabi and S.C. Gupta. 2004. Combining ability studies in tropical sorghum (Sorghum bicolor (L.) Moench). Field Crops Research 88 (2-3): 251-260.

Krifa, M., J.P. Gourlot and J.Y. Drean. 1999. Seed Coat Fragments, a major source of cotton yarn imperfections. Proceedings of the Beltwide Cotton Conference. Ed: Dugger P. And Richter D.A., pp.722-724. National Council, Memphis, TN.

Mangialardi, G.J. and W.F. Lalor. 1990. Propensity of cotton varieties to neppiness. Transactions of American Society of Agricultural Engineers 33(6): 1748-1758.

Pearson, N.L. 1955. Seed coat fragments in cotton an element of yarn quality. USDA technical bulletin No.1116. USDA, Washington, DC.

Singh, R.K., and B.D. Chaudhary. 1979. Line x Tester analysis. In: Biometrical methods in quantiative genetic analysis. New Delhi. Kalyani Publ. Company. 205-214.

Tekinsen, F. 2005. Effect of ginning on short fiber ratio, number of seed coat fragments, neps and motes of cotton having different moisture contents. University of Kahramanmaras Sutcu Imam Enstitute of Natural and Applied Science Cotton Expertise Section. MSc Thesis.

Zeng, L. and W.R. Meredith Jr. 2010. Neppiness in an introgressed population of Cotton: Genotypic variation and genotypic correlation. Journal of Cotton Science 14:17-25.

Zeng, L. and E. Bechere. 2012. Combining ability for neps, seed coat fragments and motes in upland cotton. The Journal of Cotton Science 16:17-26. 